\title{
Critical Autoethnography, Education, and a Call for Forgiveness
}

\author{
Tony E. Adams \\ Northeastern Illinois University \\ U. S. A.
}

ABSTRACT: If critical autoethnographers identify and attempt to remedy personal/cultural offenses, then they should also discuss how to live with individualsthemselves included-who have been complicit in and/or committed these offenses. One way critical autoethnographers can do so is through the concept of forgiveness. In this article, I first describe characteristics of forgiveness and establish relationships between forgiveness and critical autoethnography. I then offer three brief critical autoethnographies, each of which illustrates offenses I have experienced in educational contexts.

KEYWORDS: critical autoethnography, education, forgiveness, sexuality

\author{
Critical Autoethnography, Education, and a Call for Forgiveness \\ Forgiveness and Critical Autoethnography \\ The Music Instructor \\ Classroom Disclosures \\ Acknowledging Difficult Pasts \\ Conclusion \\ Notes \\ References \\ Author Contact
}

\section{Critical Autoethnography, Education, and a Call for Forgiveness}

Critical autoethnographies share a few key characteristics: They ascertain vital and often unforeseen connections between personal experiences and cultural experiences; identify manifestations of power and privilege in everyday practices; discern social injustices and inequities; and describe beliefs and practices that shouldand should not-exist. Critical autoethnographies also offer strategies to curtail abuses of power and privilege; challenge social injustices and inequities; change dangerous beliefs and practices; improve living conditions; promote resistance and transformation; and determine how to get along better, together, in ways that recognize and celebrate difference. $^{1}$ Thus, in essence, critical autoethnographies identify personal/cultural offenses and potential remedies for these offenses. 
Yet critical autoethnographies also should describe how to live with others who have enacted or perpetuated personal/cultural offenses, as well as consider how people carry memories and scars of offenses across the lifespan. ${ }^{2}$ For instance, how might we live with others who have intentionally and unintentionally hurt us? How do we relate to a person who has abused power and promoted injustice? What happens if we characterize a belief or practice as offensive yet others disagree? And how might we live with ourselves based on the offenses we too have committed? One way critical autoethnographers can engage these questions is through the concept of forgiveness.

In this article, I first describe characteristics of forgiveness and establish relationships between forgiveness and critical autoethnography. I then offer three brief critical autoethnographies, each of which illustrates offenses I have experienced in educational contexts. If we, as critical autoethnographers, identify and attempt to remedy personal/cultural offenses, then we should also discuss how to live with individuals-ourselves included-who have been complicit in and/or committed these offenses.

\section{Forgiveness and Critical Autoethnography}

The concept of forgiveness is premised upon three conditions: (a) an offense occurs; (b) there is an actor, typically an offender(s) and a victim(s); and (c) there is a need or desire to acknowledge and make amends for the offense. The severity of an offense can be extreme, such as with killing or sexual assault, but can also be mundane, such as when someone refuses to acknowledge another person, makes a disrespectful comment, or wishes that an offender would experience harm themselves-metaphorically, an eye for an eye. Sometimes an offense can be intentional, such as when someone assaults another person, makes a comment to shame others, or wishes someone ill will, and sometimes an offense can be unintentional, such as when a person dies in a car accident, is oblivious to the negative consequences of an action, or fails to recognize the insulting connotations of a seemingly pleasant remark or gesture.

Forgiveness involves "a change of heart, a shift in attitude, an alteration of an inner state" (Neu, 2011, p. 134); it happens when a victim overcomes resentment and contempt toward an entity-ourselves included-for committing an offense (Hagberg, 2011). If a change of heart or a shift in attitude does not occur, or should resentment and contempt exist, then forgiveness has not happened. When forgiveness does happen, the offense is no longer the "most salient feature of the offender, just as our own victimhood" is no longer the "most salient feature of ourselves in our relation to the wrongdoer" (Gerrard \& McNaughton, 2011, p. 99). With forgiveness, a person does not forget an offense, but rather develops a new relationship to the offense: e.g., recognizing cultural constraints that contributed to the offense, acknowledging their complicity or participation in the offense, and/or believing that they/others acted as best they could given particular circumstances. 
Forgiveness is important for three reasons. First, being able to forgive others, to overcome resentment and contempt, can improve our relationships. Perpetually resenting an offender leaves little hope for collaboration, improved interaction, and social justice. Second, forgiveness can encourage us to consider the ways we have committed offenses and recognize that "we may all need at times to be forgiven" (Neu, 2011, p. 136). As Gerrard and McNaughton (2011) write, even the "worst" humans are not "monsters"- "if they are monsters, then so too are we, at least potentially-there's a recurring streak of evil in the human blueprint" (p. 103). Third, forgiveness can release the burden of the past, as holding onto anxieties and pain can be exhausting and toxic. Although an offense itself may indeed feel severe, the burden of not forgiving can infuse us with hate, stress, and contempt.

If the primary purposes of critical autoethnography are to identify offenses and discuss potential remedies for these offenses, then I believe that forgiveness is an important concept for critical autoethnographers: We have a responsibility to describe how we live with others who have committed, or who have been complicit in, the offenses exposed in/by our critical autoethnographies. Our insights about forgiveness might not be applicable to all situations, but they can at least offer a sense of how to live with offenses long after they have occurred.

In the following sections, I offer three critical autoethnographies, each of which illustrates offenses I have experienced in educational contexts. I also describe how characteristics of forgiveness allow me to establish new relationships to the offenders/offenses.

\section{The Music Instructor}

I began playing the piano at the age of eight and the trumpet around ten. In the fifth grade, I joined the school band; I played in it for the next eight years. I performed solos for Catholic masses, participated in an honors band at Bradley University, and regularly served as the lead trumpeter at basketball games and school concerts. Music was the only school subject I took seriously, and, as of this writing (and with some practice), I can still play a tune by ear.

At the beginning of my last year of high school, I told the music instructor that I wanted to play trumpet in the University of Illinois at Urbana-Champaign marching band. "You are not good enough for the band," she said, laughing. I stared at her, deflated by her comment, and then sheepishly agreed. "Okay," I replied. "You know best."

Having worked with the instructor for nearly a decade, I trusted her; she was an esteemed mentor. I knew I wasn't great at trumpet and that I would need more practice, but I thought I could at least try for the band. Yet at the end of the year, I caved to the instructor's observation: I abandoned playing trumpet (and piano), suppressed any desire for making music, and decided to attend the local community college.

Thankfully, I have returned to making music, only now I use language and a computer keyboard as my instruments. I type as though I am playing the piano again. I try to write rhythmically, often singing the prose to myself to create captivating tunes 
with words. I sometimes resent my instructor and reflect on the music career that might have been. I am ashamed that I allowed one person to ruin a dream-even if she may have been insightful about my abilities. Although the encounter occurred more than two decades ago, the experience lives with me, especially when I think about the power and privilege I now wield as an instructor, advisor, and mentor. ${ }^{3}$

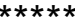

I use this example to show the influence a mentor can have on a student/career, as well as to provide an account of an unfortunate interaction that could have happened differently. The instructor could have been less flippant about my desire to play music at an advanced level; given our extensive relationship and such a meaningful topic, I expected a serious discussion. Her abrupt reaction did not feel good, and, should we have talked more about my desire, I think I would have been able to acknowledge my deficient music skills. As a critical autoethnographer, I could end here with the example and analysis: I have identified an offense, described its significance, and based on my expectations of the situation, offer suggestions about how the offense could have been avoided.

Yet I also should describe the continued significance of the offense, such as how I still live with the memory of the offender/offense and how I work toward forgiving the instructor for marking-scarring-my desires for a music career. Although I still have moments of anger and regret when I think about the influence I allowed her to have over the trajectory of my life, the concept of forgiveness allows me think about the offense in new ways. For example, I believe the instructor assumed that we had a comfortable relationship - I had worked with her for nearly 10 years and she probably assumed she could be honest with me. I wasn't the best musician, and her honesty could be interpreted as an act of care. Further, I never told the instructor about the offense, which makes me ask: How can I hold her accountable for an offense when she may not remember the interaction or ever know how the interaction may have influenced my life?

We may never know our influence on others, especially as educators who interact with many people across our careers. I often think of this interaction when I find myself monitoring what I say to students and colleagues. I know that my remarks could, at best, encourage others to take new chances, fulfill their desires, and seek satisfying opportunities; at worst, discourage them from such acts.

\section{Classroom Disclosures}

January 2005. I am an instructor of a Public Speaking course. The first assignment is a "Success Speech" designed for students to speak about a personal achievement. As I do with many assignments, I participate. I want to introduce myself to the students as well as provide an example of how an outlined speech might sound. I decide to tell of my success with coming out to my father, my success with telling him 
that I am gay. Initially, I receive a positive response from the class, but a few days later I receive a call from the chairperson of my department.

"The president of the university called me today," he reports in a serious tone. "She told me that a student's parents complained about you 'being out' as gay in the classroom. They do not think that being out is a part of the university curriculum. The president seems to agree."

Frustrated, angry, and frightened, I reply: "I don't want to hide my sexuality from students. I also used the speech as an example of the assignment. What should I do?"

"You should be out in the classroom," he says, "but rethink how you do it."

The conversation ends and I reflect on the complaint about disclosing my sexuality. An identity I claimed threatened a student, a student who will probably dislike my gay body, dislike me, for the remaining 13 weeks of the semester. For the next few years, I remain closeted in courses where sexuality has no direct relationship to course content. I fear losing my job. ${ }^{4}$

Although I felt slighted by the student, the student's parents, and the president of the university, I felt most slighted by the chairperson, my supervisor. His tempered support motivated me to worry about losing the opportunity to teach and research in an academic environment; he offered little reassurance that I would not lose my job. Yet I also did not inform him about my frustration, anger, or fear, or my expectations about what kind of support I felt was necessary. As such, how accountable should I hold him for his response? Saturated by heterosexual privilege, did he fail to recognize how the situation might have scarred me, a person who was coming to terms with his sexuality? Was his response more understandable since it happened in 2005, less understandable if it happened now given the increased acceptance of sexuality within the United States? ${ }^{5}$

I offer these questions-or rather ruminations-not to blame myself, but to provide essential context when thinking about the past. These ruminations encourage me to lessen the significance of the chair's response and thereby forgive him more, as well as release the pain, anxiety, and resentment I had about the situation. Further, as the chair of a department myself, I wonder about the ways I too have failed to offer students and faculty support, especially in moments when they needed a sense of comfort and security.

\section{Acknowledging Difficult Pasts}

Wayne-the relentless high school bully. He would take my lunch, throw food at me, hit my back, call me "fag" or "queer." Sometimes Wayne would push me into walls and out of chairs; sometimes he would steal my books; sometimes he would tease me 
for being fat. I frequently reported Wayne to school authorities, but they never intervened. His abuse escalated and I grew to hate school. At the beginning of my third high school year, I celebrated learning that Wayne decided to quit school.

And then there was Sarah, the smart and sweet girl with whom I took many classes. Although I was overweight, Sarah weighed more. And here is the shameful admission: I used to tease her about her weight, stare at her size, call her terrible names depending on the clothes she wore-sometimes asking if she purchased an outfit from a store that sold camping equipment; sometimes, if she wore purple, saying she looked like a gigantic grape; sometimes, if she wore brown, calling her a pile of shit. She probably hated school too.

During the last year of high school, I paid positive attention to Sarah, inviting her to work on school projects and to spend time together. After high school, I once drove a few hours to give her a ride home from college. In these moments, I want to remember apologizing to Sarah, but I cannot.

In addition to teasing Sarah, I also remember teasing a boy for being shy and effeminate and another boy for being soft-spoken and flamboyant. I remember another boy regularly teased for being queer-not by me, but I never defended him-who killed himself during his first year of high school. I believe that the incessant teasing contributed to his desire to die.

Another shameful admission: Although a short, fat, and reserved boy, I often felt it was necessary to try to present a tough, masculine, and heterosexual appearance. And sometimes this presentation involved hurting others. I do not know if any of these people remember my crude acts and, if they do, if they have ever forgiven me. I am also unsure if I have forgiven myself. ${ }^{6}$

I am imperfect. I make mistakes and offend others, sometimes intentionally in ways that I know, and sometimes unintentionally from a lack of reflexivity and unchecked privilege. I may have even acted in ways that, at a particular time, may have been appropriate, yet years later I come to understand as inappropriate and offensive. Reflexivity is a hallmark of critical autoethnography, and, as a critical autoethnographer, I need to be willing to share the offenses I have committed, say how I have (not) changed, and describe how I live with myself for having committed these offenses; I need to be vulnerable and describe how I too may have acted in questionable ways. ${ }^{7}$

In this example, I embrace vulnerability to describe offensive interactions that never had to happen: Wayne did not have to bully me, school authorities could have intervened, and I should have never bullied Sarah or the other students. I am most unsettled by my acts, and by sharing them-confessing them - I take responsibility for my failings-a move toward self-forgiveness. Given that I attended Catholic school for 14 years, I learned that feeling different-better-about myself is a purpose and byproduct of confession: To recount my sins to a priest was as much a recounting for myself, an attempt to release the burden of past, inappropriate acts. 
The call for reflexivity, vulnerability, and confession-all of which contribute to the process of (self-)forgiveness-may make some critical autoethnographers uncomfortable, especially if their autoethnographies describe experiences and offenses in/with educational contexts; representing tarnished selves is risky and requires privilege. ${ }^{8}$ Some autoethnographers may not have any protection to offer such accounts (e.g., stable employment, tenure), and confessing the ways in which they may have offended students or colleagues might be used against them (e.g., hiring, annual evaluations). Yet, by confessing my slights, I not only try to develop good will toward myself, but also encourage critical autoethnographers to at least think about, and take responsibility for, the offenses they too have committed.

\section{Conclusion}

Forgiveness is not a one-time occurrence, but rather a lifelong process that can be unexpectedly recalled or disrupted at various times. Often when I write, or listen to enchanting music, or hear stories about instructors harming students, I think about the discouraging music instructor. When I talk about my sexuality in class, I wonder if a student will report me to university administrators. When I find myself being rude or petty with students or colleagues, I try to refrain from engaging in bullying tactics. Forgiveness does not mean I will forget the past; rather, it allows me to reframe the relationship I have with others/offenses from the past. Further, forgiveness is not the only relevant concept when writing about these offenders/offenses; I should also consider concepts such as absolution, reconciliation, and apology.

As critical autoethnographers, many of us use personal experiences to identify offenses and possible ways to remedy these offenses. Yet we also need to show how to live with others who have offended us and/or who have been complicit in policies and systems that have inflicted significant harm. Even if personal/cultural injustices and inequities are remedied, I am not sure we can ever forget such offenses. I am not sure we could, or should, forget when mentors have failed us; or when colleagues advocated for, or engaged in, offensive practices; or when classmates said and did terrible things; or when we too may have failed as students, instructors, and administrators. In critical autoethnographies about educational contexts, we need to have more of these discussions in order to take responsibility for our offenses, improve social relations, relieve burdens of the past, and put others-and ourselves-at ease.

\section{Notes}

1. Good overviews and examples of critical autoethnography include Boylorn and Orbe (2014), Holman Jones (2016), Hughes and Pennington (2017), Briscoe and Khalifa (2015), Tilley-Lubbs and Calva (2016), and Tilley-Lubbs (2017).

2. Autoethnographers who have described others who have enacted or perpetuated personal/cultural offenses, as well as how to carry memories and scars of offenses 
across the lifespan include Berry (2012), Bochner (2012), Ellis and Rawicki (2013), Herrmann (2016), Holman Jones and Adams (2014), Rambo (2013), and Tamas (2011).

3. This story is adapted from Adams (2017).

4. This story is adapted from Adams (2010, pp. 234-35).

5. Although this situation happened more than a decade ago, the fear an instructor might have about students and administrators is still applicable. In 2010, at the same university with the same president, some community members voiced concerns about a course on queer theory (Danielson, 2010), taught by Sara Crawley, a prominent critical autoethnographer (e.g., Crawley, 2002, 2012). I think about the recent "liberal watch list" for professors who do critical research and espouse critical ideas (Mele, 2016), and I worry about the policing that could happen because of the list, from states decreasing funds for public education to administrators and politicians scouring course content.

6. This story is adapted from Adams (2016, pp. 121-22).

7. In espousing criteria for evaluating qualitative research, Bochner (2000) writes: "I almost always make a judgment about the author's emotional credibility, vulnerability, and honesty. I expect the author to dig at his or her actions and underneath them, displaying the self on the page, taking a measure of life's limitations, of the cultural scripts that resist transformation, of contradictory feelings, ambivalence, and layers of subjectivity, squeezing comedy out of life's tragedies" ( $p$. 271).

8. Berry (2016), Fassett and Warren (2007), and Pelias (2004) represent vulnerable selves in educational contexts and describe their mishaps-and even failings-as students, colleagues, and/or instructors.

\section{References}

Adams, T. E. (2010). Paradoxes of sexuality, gay identity, and the closet. Symbolic Interaction, 33, 234-256. doi: 10.1525/si.2010.33.2.234

Adams, T. E. (2016). Sexuality and self-forgiveness. Women \& Language, 39, 121-125.

Adams, T. E. (2017). Foreword. In G. A. Tilley-Lubbs, Re-assembly required: Critical autoethnography and spiritual discovery. New York, NY: Peter Lang.

Berry, K. (2012). Reconciling the relational echoes of addiction: Holding on. Qualitative Inquiry, 18, 134-143. doi: 10.1177/1077800411429088

Berry, K. (2016). Bullied: Tales of torment, identity, and youth. New York, NY: Routledge.

Bochner, A. P. (2000). Criteria against ourselves. Qualitative Inquiry, 6, 266-272. doi: $10.1177 / 107780040000600209$ 
Bochner, A. P. (2012). Bird on the wire: Freeing the father within me. Qualitative Inquiry, $18,168-173$.

Boylorn, R. M., \& Orbe, M. P. (Eds). (2014). Critical autoethnography: Intersecting cultural identities in everyday life. Walnut Creek, CA: Left Coast Press.

Briscoe, F. M., \& Khalifa, M. A. (2015). Becoming critical: The emergence of social justice scholars. Albany, NY: State University of New York Press.

Crawley, S. L. (2002). "They still don't understand why I hate wearing dresses!" An autoethnographic rant on dresses, boats, and butchness. Cultural Studies <=> Critical Methodologies, 2, 69-92. doi: 10.1177/153270860200200110

Crawley, S. L. (2012). Autoethnography as feminist self-interview. In J. F. Gubrium, J. A. Holstein, A. B. Marvasti, \& K. D. McKinney (Eds.), The Sage Handbook of Interview Research (2nd ed., pp. 143-159). Thousand Oaks, CA: Sage.

Danielson, R. (2010, January 21). USF class exploring 'queer theory' riles conservative group. Tampa Bay Times. Retrieved from www.tampabay.com/news/ education/college/usf-class-exploring-queer-theory-riles-conservativegroup/1067240

Ellis, C., \& Rawicki, J. (2013) Collaborative witnessing of survival during the Holocaust: An exemplar of relational autoethnography. Qualitative Inquiry, 19, 366-380. doi: $10.1177 / 1077800413479562$

Fassett, D. L., \& Warren, J. T. (2007). Critical communication pedagogy. Thousand Oaks, CA: Sage.

Gerrard, E., \& McNaughton, D. (2011). Conditional unconditional forgiveness. In C. Fricke (Ed.), The ethics of forgiveness: A collection of essays (pp. 97-106). New York, NY: Routledge.

Hagberg, G. L. (2011). The self rewritten: The case of self-forgiveness. In C. Fricke (Ed.), The ethics of forgiveness: A collection of essays (pp. 69-80). New York, NY: Routledge.

Herrmann, A. F. (2016). The ghostwriter writes no more: Narrative logotherapy and the mystery of my namesake. Qualitative Inquiry, 22, 588-599. doi: 10.1177/1077800415622504

Holman Jones, S., \& Adams, T. E. (2014). Undoing the alphabet: A queer fugue on grief and forgiveness. Cultural Studies $<=>$ Critical Methodologies, 14, 102-110. doi: $10.1177 / 1532708613512260$

Holman Jones, S. (2016). Living bodies of thought: The "critical" in critical autoethnography. Qualitative Inquiry, 22, 228-237. doi: 10.1177/1077800415622509

Hughes, S. A., \& Pennington, J. L. (2017). Autoethnography: Process, product, and possibility for critical social research. Thousand Oaks, CA: Sage. 
Mele, C. (2016, November 28). Professor watchlist is seen as threat to academic freedom. The New York Times. Retrieved from http://www.nytimes.com/ 2016/11/28/us/professor-watchlist-is-seen-as-threat-to-academic-freedom.html

Neu, J. (2011). On loving our enemies. In C. Fricke (Ed.), The ethics of forgiveness (pp. 130-142). New York, NY: Routledge.

Pelias, R. J. (2004). A methodology of the heart: Evoking academic and daily life. Walnut Creek, CA: AltaMira.

Rambo, C. (2013). Twitch: A performance of chronic liminality. In S. Holman Jones, T. E. Adams, \& C. Ellis (Eds.), Handbook of Autoethnography (pp. 627-638). Walnut Creek, CA: Left Coast Press.

Tamas, S. (2011). Life after leaving: The remains of spousal abuse. Walnut Creek, CA: Left Coast Press.

Tilley-Lubbs, G. A., \& Calva, S. B. (2016). Re-telling our stories: Critical autoethnographic narratives. Rotterdam, U.K.: Sense Publishers.

Tilley-Lubbs, G. A. (2017). Re-assembly required: Critical autoethnography and spiritual discovery. New York, NY: Peter Lang.

\section{Author Contact}

Tony E. Adams: tony.e.adams@gmail.com

Northeastern Illinois University: 5500 N. St. Louis Ave., FA240, Chicago, IL 60625, USA 